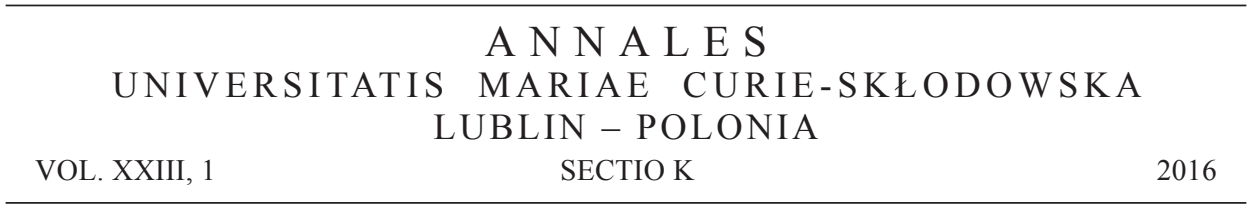

Faculty of Philosophy, South-West University "Neofit Rilski”, Blagoevgrad, Bulgaria

BORIS MANOV

\title{
The Paradigmatic Approach in Political Historiography: Nature and Solutions
}

\begin{abstract}
The present essay aims to contribute to the contemporary debate on which approach is most appropriate for political historiography. Three approaches are outlined as the most influential and widespread today: philosophico-methodological historicism, contextualism and the paradigmatic approach. The latter is investigated with respect to its characteristics, contents and heuristic parameters, and the legitimacy of its application is explained. The feature that best defines this approach is that it presents the development of political thought as a progressive, three-stage dialectical and logical process of "superseding" what is considered "outdated" and establishing new paradigms. The implementation of the paradigmatic approach in political historiography permits the birth of new political doctrines to be seen as the expression of the requirements set by the existing political paradigm in a given historical period, not as the effect of chance or divine inspiration.
\end{abstract}

Key words: political thought, history of political thought, political paradigms, contextualism, philosophical historicism, paradigmatic approach in historiography

\section{METHODOLOGY OF HISTORICO-POLITICAL SCHOLARSHIP: THE STATE OF THE QUESTION}

The present essay aims to contribute to the contemporary debate on which approach is most appropriate for political historiography. Our analysis stems from the conviction that the contemporary world is undergoing a process of "transvaluation of values" and that, in this situation, a new, topical reading of the history of political doctrines that will be adequate for modernity is needed. Bearing in mind the com- 
plexity of the problems faced by modern political theory, we shall outline the nature, contents and principal heuristic parameters of a new methodological approach - the synoptic paradigmatic one - and justify the legitimacy of its application.

The most influential and most widespread approaches in contemporary political historiography may be classified into three categories: philosophico-methodological historicism, contextualism (or, political contextualism ${ }^{1}$ ), and the paradigmatic approach. This classification is very close to the one Michael Frazer proposes in his Three Methods of Political Theory. Frazer speaks of three approaches in the history of political thought and defines them as 'ahistoricism', 'historicism' and 'transhistoricism'. As far as the first two elements of the two "systems" are concerned, it can be observed that they are very close; the two classifications differ from one another only insofar as the third approach is concerned. According to Frazer, in order to solve the opposition between ahistoricism and historicism a third approach is needed, to be situated not between but alongside them. Transhistoricism is designed in such a way that, by employing it in historical research, a new type of knowledge about the political doctrines of the past is acquired, which consists not in possessing the 'truth' about those doctrines but simply in gaining practical "wisdom" [Frazer 2010]. Conversely, our view is that a third approach should be situated not alongside but "between and above" the other two, seeking to supersede their extreme positions and to re-create their positive aspects at a higher level, so that they may fit into a new, synoptic philosophico-contextual approach.

1.1. Philosophico-methodological historicism ${ }^{2}$ is the predominant approach in historico-political scholarship. It is defended and applied mainly by continental thinkers (Hegel, Marx, Croce), or by émigrés to England or the United States (Popper, Arendt, Strauss). Its basic ideas are as follows. The point of departure is the view of the cumulative nature of the history of political thought. In line with this idea, in their studies the adherents of the philosophico-methodological approach try to outline the interconnections between different doctrines and their continual transformation and accumulation. Another fundamental thesis is the one that proposes the existence of "perennial" problems within the domain of political science which, while solved in different ways in different historical periods, are "transferred" from one doctrine, or one stage, in the history of political thought to another. The third basic statement is that in each historical period there were great or classic authors who expressed the "essence" of the political thinking of the time better and more thoroughly than others.

The first two of these views will be addressed further below. For the moment, let us focus on the third one. It should immediately be pointed out that a problem which historians generally avoid tackling arises in connection to it. This problem

1 Although it is the term 'contextualism' that has been endorsed in philosophico-methodological and political literature, we believe that 'political contextualism' is a more precise designation since this approach has been developed in relation to the history of political ideas.

2 Hans-Georg Gadamer, in his Truth and Method defines this approach as "historical thinking within tradition" in philosophy and "humanitarian (moral)" historiography in general. 
consists in the fact that there is no universally accepted definition of a "classic thinker". Consequently, when deciding about whom to include or exclude in their presentations of the political thought of the past, historians of political thought are often conditioned by personal preferences. In some cases, their preferences are determined by political bias, as in Karl Popper's The Open Society and Its Enemies. In other cases, historians plead the individual authors" "relevance", or, "influence", without, however, offering any strong evidence for the validity of these evaluations [Denzer, Maier $2007^{3}$ and $2008^{3}$ ].

1.2. Contextualism has been developed since the 1950s, mainly in English-speaking countries, and from the very outset its exponents have claimed that it signalled a turning point in the methodology of political historiography. It has been promoted by a group of scholars at Cambridge: Peter Laslett, Quentin Skinner and John Pocock; hence, this group is known as "The Cambridge School". The turning point sought by the founders of contextualism consists, on the one hand, in criticizing philosophico-methodological historicism (this term is not used by the founders of the school: they refer instead to "political philosophy", and the approach is defined as "traditionalism" by Pocock, as "essentialism" by Skinner, etc.) and, on the other hand, in justifying their own, "original" approach, which is intended to serve as a basis for a "truly historical" investigation into the history of political thinking and into the ideas of individual authors of the past. ${ }^{3}$

According to Laslett, Skinner and Pocock, philosophico-methodological historicism has outlived its usefulness and revealed its methodological inconsistency. Their critical arguments can be summarised in two points: 1) They reject the existence of "perennial" problems and of "basic concepts" in the history of political thought [Skinner 1969: 5, 37, 50-51]. 2) They reject the existence of any "logic" in the development of political thought which would predetermine the nature and contents of political ideas in a given historical period. Instead, the contextual approach promoted by the three scholars demands that any politico-theoretical text that becomes the subject of study and interpretation should first be suitably collocated within the concrete historical context from which it stems. According to Pocock, this can be achieved through the analysis of "political language" [Pocock 1972]; for Skinner - through the analysis of the "speech act" - the goal of historical study is the explanation of "what a given writer may have said, and what he may be said to have meant by saying what he said" within the context of a particular political practice [Skinner 1969: 31]. "True historicism" concerns "empirical" work on concrete texts and verifiying the interpretations proposed by comparing them with the political languages of the epochs in which these texts were composed. ${ }^{5}$ The contrary implies

3 Cf. Pocock 1957 and 1975; Laslett 1960 and 1965; Skinner 1978.

4 Tim Stanton [see Stanton 2011] is of the same opinion.

5 A standpoint flatly rejected by one of the most distinguished representatives of philosophico-methodological historicism, the Italian Benedetto Croce, who defines it as an "archaeology" when dealing with historical texts, rather than as an "historical" study of these texts. Cf. Croce 1921. 
that meanings which cannot be found therein are introduced into the texts analysed 6 [Skinner 1969: 9-12, 17, 42], and therefore, as a result, the true history of political thought is compromised. ${ }^{7}$

1.3. The paradigmatic approach in the history of scientific knowledge, despite its long "prehistory", became a crucial issue after the publication of the "scientific bestseller" by Thomas Kuhn The Structure of Scientific Revolutions in 1962. The widespread dissemination of this approach is one of the factors which determine the incoherence of the way in which the key term "paradigm" is used by different authors. Actually, it is Kuhn's definition of 'paradigm' itself that predetermined the subsequent discussions; this is so, despite the fact that Kuhn imposed considerable limitations with regard to the possibilities for implementing his approach. ${ }^{8}$ Researchers on Kuhn's work (for example, Margaret Masterman) point out that The Structure includes more than twenty views of what 'paradigm' means [Masterman 1970: 61-62], a problem that Kuhn tried to solve by employing the term 'disciplinary matrix' in the second edition of the book, published in 1969. The new term was meant to specify and "discipline" the notion of paradigm [Kuhn 1970²: 162-204].

It must be stressed that it is not only Kuhn who confines the application of the paradigmatic method to natural sciences alone. On this, the representatives of the Cambridge School agree with Kuhn. John Pocock says that at first he was impressed by the possibilities opened up by the paradigmatic approach but subsequently arrived at the conclusion that the study of the history of socio-political knowledge was possible only if based on the application of the method of contextual analysis [Pocock 2008: XI-XIV].

Kuhn's scenario, he writes, was obviously a highly political one, and I was encouraged to believe that the notion of the 'paradigm' would prove applicable to the inquiry I was conducting into the rise, transformation and disappearance of political 'languages'. A new 'language', it seemed plausible, might dictate a new concept of politics and of the political community itself. An association between my methodological writings and Kuhn's work is therefore proper; but as early as 1971 I was doubtful about carrying it too far, and knew that these doubts were shared by Kuhn himself [Pocock 2008: XI].

In his Meaning and Understanding, Quentin Skinner also emphasizes the "heuristic nature" of the paradigmatic approach in the history of arts and sciences but rejects its applicability in the history of ethics, religion and politics. He claims that,

${ }^{6}$ Cf. also the following passage: "Similarly, we need to be able to cope with the intractable possibility that certain of the classic philosophical texts may contain quite a large number of what contemporaries would instantly have seen to be jokes. Plato and Hobbes perhaps spring to mind: again, this would obviously be an important clue to the understanding of their texts, but, again, it is hard to see how either of the approved methodologies can help" [Skinner 1969: 48].

7 For detailed accounts of contextualism, see Browning 2016 [pp. 67-88], as well as Koikkalainen 2011 and 2015, Frazer 2010, Lamb 2009.

8 For example, its dubious effectiveness in the field of humanitarian knowledge [Kuhn 1970²:10-23]. 
as far as the field of the humanities is concerned, this approach leads to the development of moral, religious and political mythologies. ${ }^{9}$ However, Skinner sets forth no clearly formulated arguments to show that the use of the paradigmatic approach creates mythologies in "the historical study of ethical, political and religious ideas" but does not create them in the domains of art and science. This fact might be seen as one of the reasons why the attempt to confine the paradigmatic approach to the sphere of natural sciences alone proved unsuccessful. The psychological, rather than logico-methodological, nature of Pocock' arguments, together with Kuhn's theoretical irresoluteness, might be indicated as further reasons for this development. ${ }^{10}$

Despite the opinions of Kuhn, Skinner and Pocock, the paradigmatic method is extensively applied outside the field of the natural sciences and has made its way into philosophy and politics. As far as the contents of the concept of 'paradigm' in the field of the humanities are concerned, its meaning has been shown to cover a far wider field than it does in Kuhn. Among its proponents are Madan Handa and Terence Ball [Handa 1987; Ball 1976], and it shares some common ground with Lakatos' notion of 'scientific research programs'. It is also present in Hans Küng's notion of 'macroparadigms', in Aleksandr Dugin's notion of 'super-encompassing paradigms' and in Alexandar Kanev's 'supra paradigms' [Küng 2007: 142-146; Dugin 2002: 12-17; Kanev 2010: 175-182]. This broader notion of the term 'paradigm' is employed in the present study.

\section{THE PARADIGMATIC APPROACH IN POLITICAL THEORY (AND HISTORIOGRAPHY)}

To base historiographical practice on the employment of the paradigmatic approach means making use of a new, "synoptic", view of the history of political thought. According to this standpoint, the history of political thought should not be considered a mere chronology of facts. Neither should it be considered a linear

9 "This notion of the priority of paradigms", Skinner writes, "has already been very fruitfully explored in the history of art, where it has caused an essentially historicist story which traced the development of illusionist to yield place to a story which is content to trace changing intentions and conventions. More recently an analogous exploration has been made with some plausibility in the history of science". Such is not the case with the "historical study of ethical, political, religious, and other such ideas", where "it is a dangerously short step from being under the influence (however unconsciously) of such a paradigm to 'finding' a given author's doctrines on all of the mandatory themes. The (very frequent) result is a type of discussion which might be labelled the mythology of doctrines" [Skinner 1969: 6-7, 23-24, 40].

${ }^{10}$ Kuhn does not remain a firm proponent of the notion of paradigms as presented by him in The Structure. For various reasons, including the criticism he received after the second edition of the book, during the $80 \mathrm{~s}$ he arrives at the assumption, which, however, is not developed as an overall conception, that there is a common bond between the humanities and the sciences, on account of which it would be possible to apply the paradigmatic approach in the field of the humanities as well. At that point, it became preferable to use the broader equivalent ("hermeneutic core") of the term 'paradigm', rather than the "narrow" meaning [cf. Kuhn 1991: 17-24]. 
process of the accumulation of political ideas, or as a set of separate "contextual" analytical texts. Its exponents regard political historiography as an attempt to "reconstruct" the process of the historical development of political doctrines, i.e. to create a theoretical model for the dialectical "becoming" of the history of political thought.

The view of historiography as a "reconstruction" is the most widespread and, at the same time, the one most contested in philosophico-methodological literature. ${ }^{11}$ The reason for this is the fact that a "reconstruction" of the doctrines of the past presupposes, on the one hand, that the scholar approaches the historical process in such a way as to guarantee the logical coherency of the reconstruction proposed. One of the most avowed proponents of reconstructive historiography in the humanities, Richard Rorty, is explicit about such an understanding of 'reconstruction'. According to him, when we engage in rational reconstruction,

we should treat the history of philosophy as we treat the history of science. In the latter field, we have no reluctance in saying that we know better than our ancestors what they were talking about (...) Each of these imaginary people, by the time he has been brought to accept such a new description of what he meant or did, has become 'one of us'. He is our contemporary, or our fellow-citizen, a fellow member of the same disciplinary matrix. [Rorty 1984: 71]

On the other hand, the view of historiography as a "reconstruction" can be contested in that it implies the risk of producing a "history" which exists only "inside the head of its creator". As Jerry Fodor aptly points out, not only might historical reconstructions utterly disregard the ideas of the thinkers they claim to interpret, but even the paradoxical situation might occur in which someone writes a "book about Hume without actually knowing anything about him" [Fodor 2003: 1].

Although the risk of which Fodor warns us is real, we also have to admit that working on the basis of reconstructive theoretical models is a powerful and efficient mechanism for the realization of historiographical studies. This is so thanks to two factors. First, as Dimitar Ginev points out, the models of scientific development, taken in the broadest sense, provide an answer to the question "How is a rational reconstruction of scientific development possible?". This answer consists in the formulation of a system of rational standards (rules, norms, requirements) that are used as the basis for the exploration of the dynamics of scientific knowledge. Reconstructive theoretical models also serve as a basis for the theoretical modelling of scientific development. These models provide the "methodological instruments" for completing the "reflexive" encompassing of the history of scientific development, that is, its "rational reconstruction" through the prism of its intrinsic dynamics [Ginev 1986: 11-17, 20-24]. Second, as Benedetto Croce writes in one of the appendices to his Theory and History of Historiography, published in 1917, without the foundation of a theoretical model

\footnotetext{
${ }^{11}$ For a discussion of this view, see Frazer 2010.
} 
(that is, "the system of requirements of philosophical methodology"), history is either an "empirical chronology" of "archaeological facts", or "abstract metaphysics", but never a "living" theory of the historical process [Croce 1921: 151-164].

Bearing in mind the nature of reconstructive theoretical models as outlined above, the model that innovative political historiography should seek to endorse is characterized by the following traits:

2.1. The model is derived from a particular notion of the term 'paradigm', which is essentially different from Kuhn's and which basically presents the 'paradigm' as the ideal of scientificity shared by a given scientific community. Kuhn's notion can be defined as sociological or socio-political, for it takes as its principal criterion the "contract", i.e. the achievement of "consensus" in a given scientific community, concerning the acceptance of one or another "ideal" of scientificity. It is in this way that Pocock views paradigms, which gives him good reason to reject the possibility of applying the paradigmatic approach to political science. In his opinion, in political life there are, not just hypothetically but also necessarily, competing communities, and, as a consequence, there is a multitude of competing political conceptions. According to Pocock,

the scientific community, though it has its own politics and interacts with the politics of others, differs radically from what may be termed the political community (...) The political community is not essentially, though it is incidentally, a community of inquiry, and the 'paradigms' it from time to time generates to define it as a community dealing with certain problems, and having a certain structure, operate within a multiplicity of problem-situations so great that no one 'paradigm' can long succeed in excluding or occluding its alternatives. [Pocock 2008: XII-XIII]

This fact, Pocock continues, renders the use of the term 'paradigm' in political theory and historiography pointless. Politics is "anti-paradigmatic", "anti-revolutionary" and "anti-cumulative", and for this reason we cannot speak of universal ideals in political scholarship. ${ }^{12}$

By contrast, the notion of 'political paradigm' ${ }^{13}$ offered in the present study is based not on the socio-political but on the epistemologico-methodological approach. In this perspective, the most general "matrices" of thought which define the cognitive "code" for explaining and conceptualizing political reality are designated as 'political paradigms'. Taken in this sense, a 'paradigm' is not related to a particular scientific or political community at a certain time; rather it constitutes the model (or,

${ }^{12}$ On the non-revolutionary character of paradigms, see also Pocock [1972: 273-291], as well as The Discovery of Islands, which was published years later and in which he emphasizes: "There is no history which is not many-sided, and no reading to which there are not alternatives" [Pocock 2005: IX].

${ }_{13}$ Paradeigma, $\pi \alpha \rho \alpha ́ \delta \varepsilon 1 \gamma \mu \alpha$ - a model, example or pattern for something that may be copied; a theory or a group of ideas about how something should be done, made, or thought about. 
the pattern) ${ }^{14}$ followed by political thinkers and viewed by them as self-evident and mandatory. In addition, it outlines the "ultimate" principles of the mechanisms, by means of which a given concept of politics and political reality is achieved. In this way, political paradigms encompass large periods in the history of political theory, and any change of paradigm essentially causes new stages in this history. What is crucial in this notion of political paradigms is the unity of meaning and dynamics inherent in them, making it essentially different from the existing concepts, which accept the possibility of applying the paradigmatic approach to the humanities.

2.1.1. The first step to be taken is to define the differentia specifica of paradigms in the system of human knowledge. This problem has not received due attention in the existing studies, where paradigms are often reduced to some related cognitive phenomena, such as 'worldview'. Their function as models (patterns) or, matrices for the realization of political doctrines, is what differentiates political paradigms from related cognitive phenomena. The principal dissimilarity consists in the fact that 'worldview' refers to the cognitive image which dominates the social consciousness in a given historical period, while the paradigmatic model defines the mechanism for achieving particular cognitive goals, i.e. it is not mainly of a descriptive but, above all, of a prescriptive character. In this way, the paradigmatic model outlines, in a given historical period, the framework, the means and the goals of the subject's knowledge and, by doing so, it emerges as a method for the construction of political doctrines. Political doctrines are theoretical conceptions based upon the dominant political paradigms, granting them both conceptual and factual content and combining within themselves both cognitive and ideological (biased) statements.

The relationship between 'truth' and 'value' is one of the most significant problems of social knowledge, in general, and of political knowledge, in particular. This relationship was a subject of debate within the neo-Kantian school, whose exponents proposed a classification of the sciences in nomothetic (basically the natural sciences searching for truth) and ideographic sciences, which use a qualitative approach and thus search for values. Max Weber maintained that social and political theory, like the theory of natural sciences, should strive for the ideal of "emancipation from values" in the field of social sciences in order to become a truly scientific theory. ${ }^{15}$ In modern political literature, a similar standpoint is assumed by political contextualism [Pocock 2008: 269]. Its theoretical roots can be traced back to Weber's ideas, as well as to methodological empiricism in political knowledge, proclaimed and conducted by philosophical neopositivism [cf. Skodo 2013] and its narrow scientific manifestation - behaviourism. This view, if consistently pursued, predetermines the transformation of historico-political study into "archaeology" (to use Benedetto

${ }^{14}$ In the Republic (592b), Plato states that the ideal state probably has its ideal 'example' $(\pi \alpha \rho \alpha \delta \delta \varepsilon \gamma \mu \alpha)$ in heaven and in Timaeus (28a) he claims that the 'Demiurge', i.e. the 'one who creates something', always follows a 'model' ( $\pi \alpha \rho \alpha \dot{\delta} \delta \varepsilon \gamma \mu \alpha)$ in his work. Cf. Plato 1969, where $\pi \alpha \rho \alpha ́ \delta \varepsilon 1 \gamma \mu \alpha$ is translated as 'pattern', and Plato 1925, where $\pi \alpha \rho \alpha \delta \delta \varepsilon 1 \gamma \mu \alpha$ is translated as 'model'.

${ }^{15}$ Cf. Weber 1904 and 1917. 
Croce's term). It has been rejected, by authors such as Rawls, as delimiting and distorting political knowledge. In fact, even its radical proponents, such as Pocock and Skinner, have not employed it straightforwardly, and in his late essays where he deals with political ideologies, Skinner defines them as "ahistorical", or, "perennial" political conceptions [Skinner 2002: 147-149].

This essay aims to show the strengths of a view of political doctrines as a conceptual "hybrid" endowed with both "truth" and "value", being both a science and an ideology and cognizing social reality, besides affording instructions to social agents in order for it to be actively formed and transformed. From this perspective, political doctrines are seen not only as more or less faithful descriptions of the existing political reality but also as proposals or programs for its improvement, based on the relevant paradigmatic models. Thus, political doctrines also become "guidelines for action" and might even contain "instructions" concerning the question as to which individuals can best perform the actions needed in order to construct the perfect edifice of the ideal state.

A central element in the paradigmatic approach is the definition of the basic "cell" of political reality and its conceptualization in political thought. This definition would enable us to focus our analysis on the main issue, the "core", in which inhere, and from which stem, all the elements of each particular doctrine. It is not by chance that in Karl Marx the definition of the basic 'cell' is the starting point in the study of the political economy of capitalism and that the first chapters of his Capital are devoted to this definition. In these chapters, Marx formulates the statement that "in bourgeois society, the commodity-form of the product of labour - or value-form of the commodity - is the economic cell-form", a concept which he considers his most significant contribution to economic theory and which "the human mind has for more than 2,000 years sought in vain to get to the bottom of it all" [Marx 1996: 7].

Defining the "cell" of historico-political study is a manifestation of the "covert" transition of some Cambridge scholars to the field of philosophico-methodological historicism and the syncretic paradigmatic approach. Indicative of this is the approach of Pocock, who thinks that the "core" of political doctrines since Machiavelli has been the problem of "republicanism", defining the "dominating" spirit of politics at the time. This standpoint is expressed in The Machiavellian Moment: Pocock indicates "republicanism" as the prevailing spirit of politics and the core of the political doctrines that have developed since the age of Machiavelli. According to Pocock, his work on the Italian political thinker "should be read as the history of the dialectic between the Republic and its alternatives". Further down in the text, he defines 'sovereignty' as such a core: "I take it to be an exercise of the sovereignty, autonomy or self-command of a civil society that it can narrate, re-narrate and interpret its history, with the consequence that it recognizes sovereignty even in this sense to be contestable, conditional and in short historical". But this shift of emphasis does not essentially change the fact that he was searching for the "essential core" of political 
theory and that, as a consequence of this, he went beyond the boundaries of the contextualism that he professed. ${ }^{16}$

In the present essay, the role of the basic cell of political theory and reality is reserved for the State. This is due to the fact that the State is the only element in the system of politics that has been constantly present in history. For a long period, from the rise of the first state formation, in about the tenth-seventh century B.C., and until the age of the Enlightenment, it was the only clear manifestation of the political and, consequently, it was the object and subject matter of political theory. It was only after the Enlightenment that new political subjects emerged, but even in this new situation the State has retained its role as a central political institution. In this later period, the object of the analysis of political theory has become broader; however, the State, with its functions, still represents the main interest of political thinkers.

In the contemporary world, the role of the State has significantly changed. Nevertheless, its importance has not diminished. On the contrary, indeed, it has even grown, and this is due to several factors. Nowadays it is only the State that can effect the necessary consolidation of the political, financial-economic and cultural-ideological means and social forces that are to provide, in unison, the successful inclusion of historically established social communities (at present, mainly the nations) in the increasingly intensive processes of globalization. In order to achieve this aim, the State has to promote the development of scientific research and the implementation of high-tech production; it has to provide the training of the professionally qualified cadres required by such activities, to provide the conditions for overcoming demographic disproportions and social stratification, to guarantee social and ethnic peace, and so on. Moreover, particularly for countries on the civilizational "periphery", the State plays an extremely important role in the creation and maintenance of social structures. By mobilizing the abilities of all social powers on the basis of the unity of what is nationally specific or traditional and what is contemporary and universal, the modern State can ensure the progressive development of, and the integration into, the modern civilizational process, both of which are commensurate to its nature, and, at the same time, oppose the aggressive advance of hegemonic, narrow models of the existence of the world in the global age. This fact has been recognized even by Francis Fukuyama although he is known as one of the strong proponents of the philosophy sustaining less state power in the modern world. ${ }^{17}$

The fact that the State is the "cell" of political doctrines has been admitted, albeit critically, by Quentin Skinner, as well. In Meaning and Understanding he points out:

Perhaps the most remarkable evidence of the hold of this most essentialist approach is that it was never questioned, as a method of discussing the history of political ideas, even by the most anti-essentialist of all contemporary political theorists, T. D. Weldon.

\footnotetext{
${ }^{16}$ Cf. Pocock 1975: 561-563 and Pocock 2008: x.

${ }^{17}$ Cf. Chapter Three, "Weak States and International Legitimacy" in Fukuyama 2004.
} 
The first part of his book on States and Morals ${ }^{18}$ sets out the various "definitions of the State" which political theorists all "either formulate or take for granted". It is thus established that "all theories of the State fall into two main groups. Some define it as a kind of organism, others as a kind of machine". Armed with this discovery, Weldon then turns "to examine the leading theories about the state which have been put forward". [Skinner 1969: 14]

Once the basic cell of political theory and practice has been defined, the paradigmatic model moves on to outline a universal, invariant model of the political as a social phenomenon. However, the realization of such a model is only possible by taking into account the "most well-developed" form of the political and not by tracing its "becoming". This approach permits us to grasp the theoretical object in its "purest" form, ${ }^{19}$ emancipated from historically induced contingencies. ${ }^{20}$ On the basis of the paradigmatic model thus constructed, it is possible to outline several interwoven problem fields which together constitute a "matrix" for understanding the political [Dugin 2002: 13-25]. The first problem field concerns the basic question of political theory, which will be discussed further below in this essay. The second deals with defining the nature and meaning (the purpose) of the existence of the State and with elaborating a project for the future development of society. The third problem field concerns the matter of political power along with the principles and criteria for defining its subjects. The fourth deals with defining the role of the law in society and clarifying the meaning and hierarchy of forms of government. The fifth field is concerned with issues such as the role of the State in the management of social relations and the establishment of the social structure of society. The last one deals with the issues of how a value system is created as a form of community consciousness and how to effect a collective identification of the citizens with a state.

2.1.2. The idea of a basic question of political knowledge clearly contradicts contextualism since the hypothesis of the existence of "perennial" problems is one of the favourite targets of critics of its proponents. In fact, following Collingwood, Skinner asserts that "there simply are no perennial problems in philosophy: there are only individual answers to individual questions, with as many different answers as there are questions, and as many different questions as there are questioners", and "there is in consequence simply no hope of seeking the point of studying the history of ideas in the attempt to learn directly from the classic authors by focusing on their attempted answers to supposedly timeless questions" [Skinner 1969: 50].

As Lamb points out, Skinner actually illegitimately identifies the term 'eternal', taken by Collingwood to mean 'metaphysically eternal' or 'transcendentally eter-

${ }^{18}$ Weldon 1946.

${ }^{19}$ Such is Marx's approach in the Introduction to his A Contribution to the Critique of Political Economy (1959). Cf. in Marx 1977.

20 "Contingency must vanish on the appearance of Philosophy", Hegel writes in the Introduction to his Lectures on the History of Philosophy [Hegel 1892: 36-37]. 
nal', i.e. inescapably intrinsic in existence, with the term 'perennial', and on this basis rejects the existence of 'eternally renewed' problems in the history of political thought and in the history of human knowledge in general [Lamb 2009: 13-14]. On the contrary, the standpoint assumed in the present study is based on the distinction between the 'metaphysical' and the 'epistemological' ways in which 'perennial' theoretico-historical problems are understood.

We designate the question concerning the reason for the rise and existence of politics in society as the basic problem of political theory. In the history of political thought, there are three essentially different solutions to this problem. These three solutions define the three paradigms in the history of European political thought: the cosmologico-theological, the socio-humanistic and the cosmologico-humanistic. According to the first solution, the reason for the existence of politics is located outside human society - either in the universal harmony (or, cosmic harmony) of all existing things inherent in "nature", or in the nature and the structure of the world predestined by the creative power of God. On the basis of this solution, a paradigm is formed which can be defined as cosmologico-theological. According to the second solution, politics is already inherently attributed to society, and it is the people with their creative potential who determine the type of political organization. In this way, the socio-humanistic political paradigm is formed. The third solution attempts to combine the conceptual cores of the previous two and is connected to elaborating a political paradigm which can be defined as cosmologico-humanistic. The meaning thus outlined of the three-stage model in the development of political knowledge is an essential characteristic of the paradigmatic approach, taking as its principal trait the unity of suspension and cumulativity, which is the origin of its basic methodological and cognitive advantage in contrast to philosophico-methodological historicism (political philosophy) and to the "traditional" notion of the paradigmatic approach in reflexive political historiography.

Despite the variety of views that favour the possibility of applying the paradigmatic approach to the field of social and humanitarian knowledge, the emphasis usually falls on the 'paradigm shift' and its role in social practice. ${ }^{21}$ In opposition to these views, our position is that the paradigmatic approach should not merely be reduced to revealing the conditions for the realization of paradigmatic shifts, although we admit their importance in the historical development of political thought. As a more appropriate model for describing this development, we acknowledge the three-stage model in which old paradigms are dialectically "superseded" by new ones. This process of dialectical development is generally aimed at achieving a synthesis in which the explanatory "matrix' of the third paradigm "sublates" in itself the matrices of the two preceding ones. By means of this dialectical model,

${ }^{21}$ Madan Handa, for example, sees the role of the paradigmatic approach in orienting social knowledge towards uncovering the social prerequisites of the paradigmatic shift, its manifestations, its mechanisms, and its effects on the structure and functioning of society [cf. Handa 1987]. 
the history of political thought acquires its own internal logic and order. This fact possesses a special methodological significance since, as has already been mentioned, despite the possibility, proclaimed by various authors, of applying the paradigmatic approach to social and humanitarian knowledge, such an application, on account of the aforementioned critical standpoint assumed by the Cambridge School, is almost absent in studies on political science. Yet, in Russian political science, one could witness some attempts to use the term 'paradigm' to explain the development of political knowledge. However, since the usage is "mechanical", covertly introduced, not "conceptualized" or elevated to a consciously conducted theoretico-methodological approach, the views presented on the political paradigms are chaotic. Indicative of this is the standpoint of Aleksandr Solov'ev, who after formulating three political paradigms in the process of his exposition, then proceeds to 'multiply' them to about ten, without clarifying what the logical or the chronological relations between them are, or if any such relations exist in the first place [Solov'ev 2014: 29-35].

2.2. The paradigmatic reconstructive model is related to the application of a specific, historico-hermeneutical approach manifested in two methodological prescriptions. In the first place, and in accordance with Hegel's dialectical tradition, this model demands that historians of political doctrines should confine themselves to an analysis of the sources, that is, of the original philosophical works of the past, and that they should be "cautious not to introduce foreign matter" and not to ascribe to the authors "more than is found in history"22 [Hegel 1892: 43]. Benedetto Croce points out in a similar vein:

A history without relation to the document would be an unverifiable history; and since the reality of history lies in this verifiability, and the narrative in which it is given a concrete form is historical narrative only in so far as it is a critical exposition of the document, a history of that sort, being without meaning and without truth, would be inexistent as history. [Croce 1921: 14]

In this connection, contextualists like Quentin Skinner warn against separating the 'text' of the philosophical works analysed from their 'context'. "The danger of writing historical nonsense", he writes, "in direct consequence of concentrating on the text in itself, is often incurred, and indeed very seldom avoided altogether in current practice", and this possibility is most vividly manifested in the so called genre of 'intellectual biography' and in the 'histories of ideas'. Precisely through reference to this type of investigations, "where the morphology of the doctrine itself is traced out", Skinner rejects the use of the original text as a basis for the historical study

${ }^{22}$ Hegel writes further: "The history of Philosophy has simply to deal with this development and bringing forth of thought. (...) We must therefore only make use of the words which are actually literal, for to use further thought determinations which do not yet belong to the consciousness of the philosopher in question, is to carry on development" [Hegel 1892: 44]. 
[Skinner 1969: 31]. With this, he makes an unfair evaluation of the paradigmatic reconstructive model, for, in reality, together with the demand to base historico-political research on a good knowledge of the sources, this approach also prescribes that the concrete historical socio-political and spiritual conditions and influences must be taken into account.

Interestingly, this second requirement of the paradigmatic model is not considered without reservations by Skinner, either. Skinner believes that what he calls "political philosophy" sociologizes historical analysis. In the article quoted above, he points out: "The methodology of contextual reading, in both its Marxist and Namierite versions (they are oddly similar) can itself be shown to rest on a fundamental mistake about the nature of the relations between action and circumstance", on account of which "the fundamental assumption of the contextual methodology, that the ideas of a given text should be understood in terms of its social context, can be shown to be mistaken, and to serve in consequence not as the guide to understanding, but as the source of further very prevalent confusions in the history of ideas" [Skinner 1969: 42-43].

To summarise, the reflexive paradigmatic approach of historical research functions like binoculars and combines a good knowledge of the original texts and an acknowledgment of their historical conditioning in order to reconstruct the doctrines of the past. In this way, it reduces the risk of separating the "text" from the "context" as well as of placing too narrow an emphasis on either the contextual or the sociological analysis. At the same time, it is only possible to effect a reconstruction of the history of political thought from the point of view of the present; and any such reconstruction can only be an original account of the doctrines of the past, since the "emancipation from the obstructive contingencies" presupposes an active intervention on the part of the historian and his imposing on the material his own, "unifying" "intentional" view [cf. Green 2012]. Hans-Georg Gadamer adds to this, that

It is by no means settled (and can never be settled) that any particular perspective in which traditionary thoughts present themselves is the right one. "Historical" understanding, whether today's or tomorrow's, has no special privilege. It is itself embraced by the changing horizons and moved with them. [Gadamer 2004b: 531]

Furthermore, by establishing the unity of text and context, political historiography protects itself from unwarranted modernization and from the representation of the political doctrines of the past outside their historical context. In this way, by binding into one "our own present" and "the depths of its historical consciousness" (as Gadamer puts it), the paradigmatic approach gives us the possibility to acquire knowledge both of the past and the future of human society: for "history is only present to us in the light of our futurity" [Gadamer 2004a: 8-9]. 


\section{BIBLIOGRAPHY}

Ball, T. 1976. From Paradigms to Research Programs: Toward a Post-Kuhnian Political Science, "American Journal of Political Science", vol. 20, pp. 151-177.

Browning, G. 2016. A History of Modern Political Thought: The Question of Interpretation, Oxford University Press, New York.

Croce, B. 1921. Theory and History of Historiography, trans. D. Ainslie, George G. Harrap, London.

Denzer, H., Maier, H. eds. 2007³. Klassiker des politischen Denkens, Bd. I, C.H. Beck, München.

Denzer, H., Maier, H. eds. 2008³. Klassiker des politischen Denkens, Bd. I, C.H. Beck, München.

Dugin, A. 2002. Èvoljucija paradigmal'nyh osnovanij nauki, Artogea, Moscow.

Fodor, J. A. 2003. Hume Variations, Oxford University Press, New York.

Frazer, M. 2010. Three Methods of Political Theory: Historicism, Ahistoricism and Transhistoricism (draft for presentation at the 2010 CPSA), http://www.cpsa-acsp.ca/papers-2010/Frazer.pdf (access 15.05.2016).

Fukuyama, F. 2004. State-Building: Governance and World Order in the 21st century, Cornell University Press, Ithaca, New York.

Gadamer, H.G. 2004a. Philosophical Hermeneutics, trans. D. E. Linge, University of California Press, Berkley et al.

Gadamer, H.G. 2004b. Truth and Method, 2nd rev. edition, trans. J. Weinsheimer and D. G. Marshall, Crossroad, New York.

Ginev, D. 1986. Modeli na naučnoto razvitie, Nauka i izkustvo, Sofia.

Green, J. 2012. On the Difference Between a Pupil and a Historian of Ideas, "Journal of the Philosophy of History", vol. 6, pp. 84-112.

Handa, M. 1987. Peace Paradigm: Transcending Liberal and Marxian Paradigms (paper presented at the "International Symposium on Science, Technology and Development", New Delhi, India, March 20-25).

Hegel G. W. F. 1892. Lectures on the History of Philosophy, trans. E. S. Haldane, vol. 1, Kegan Paul - Trench and Trübner, London.

Kanev, A. 2010. Teorija na filosofskoto razvitie, Sofia University Press, Sofia.

Koikkalainen, P. 2011. Contextualist Dilemmas: Methodology of the History of Political Theory in Two Stages, "History of European Ideas", vol. 37, pp. 315-324.

Koikkalainen, P. 2015. The Politics of Contextualism: Normativity and the New Historians of Political Thought, "Journal of the Philosophy of History", vol. 9, pp. 347-371.

Kuhn, Th. $1970^{2}$. The Structure of Scientific Revolutions, University of Chicago Press, Chicago.

Kuhn, Th. 1991. The Natural and the Human Sciences, [in:] The Interpretative Turn. Philosophy, Science, Culture, D. R. Hiley, J. F. Bohman, R. Shusterman (eds.), Cornell University Press, Ithaca and London, pp. 17-24.

Küng, H. 2007. Islam: Past, Present \& Future, trans. J. Bowden, Oneworld Publications, Oxford.

Lamb, R. 2009. Quentin Skinner's Revised Historical Contextualism: A Critique, "History of the Human Sciences", vol. 22, pp. 51-73

Laslett, P. 1960. Introduction, [in:] Two Treatises of Government, J. Locke, Cambridge University Press, Cambridge, pp. 3-120.

Laslett, P. 1965. The World We Have Lost, Methuen, London.

Marx, K. 1977. A Contribution to the Critique of Political Economy (1959), trans. S. W. Ryazanskaya, Progress Publishers, Moscow.

Marx, K. 1996. Capital, in Marx and Engels Collected Works, vol. 35, Lawrence and Wishart, London.

Masterman, M. 1970. The Nature of a Paradigm, in Criticism and the Growth of Knowledge, eds. I. Lakatos, A. Musgrave, Cambridge University Press, Cambridge.

Plato 1925. Timaeus, in Plato in Twelve Volumes, vol. 9, trans. W. R. M. Lamb, Harvard University Press and William Heinemann Ltd, Cambridge, MA and London. 
Plato 1969. The Republic, in Plato in Twelve Volumes, vols. 5 \& 6, trans. P. Shorey, Harvard University Press and William Heinemann Ltd, Cambridge, MA and London.

Pocock, J. G. A. 1957. The Ancient Constitution and the Feudal Law: a Study of English Historical Thought in the Seventeenth Century, Cambridge University Press, Cambridge.

Pocock, J. G. A. 1972. Languages and Their Implications: the Transformation of the Study of Political Thought, [in:] Politics, Language and Time: Essays on Political Thought and History, J. G. A. Pocock (ed.), Methuen, London, pp. 3-41.

Pocock, J. G. A. 1975. The Machiavellian Moment: Florentine Political Thought and the Atlantic Republican Tradition, Princeton University Press, Princeton.

Pocock, J. G. A. 2005. The Discovery of Islands. Essays in British History, Cambridge University Press, Cambridge.

Pocock, J. G. A. 2008. Political Thought and History: Essays on Theory and Method, Cambridge University Press, Cambridge et al.

Rorty, R. 1984. The Historiography of Philosophy: Four Genres, [in:] Philosophy in History, R. Rorty, J. B. Schneewind, Q. Skinner (eds.), Cambridge University Press, Cambridge.

Skinner, Q. 1969. Meaning and Understanding in the History of Ideas, "History and Theory", vol. 8, pp. 3-53. Skinner, Q. 1978. The Foundations of Modern Political Thought, Cambridge University Press, Cambridge. Skinner, Q. 2002. Visions of Politics. Vol. 1: Regarding Method, Cambridge University Press, Cambridge.

Skodo, A. 2013. Analytical Philosophy and the Philosophy of Intellectual History: A Critical Comparison and Interpretation, "Journal of the Philosophy of History", vol. 7, pp. 137-161.

Solov'ev, A. 2014². Politologija. Političeskaja teorija. Političeskie tekhnologii, Aspent Press, Moscow.

Stanton, T. 2011. Logic, Language and Legitimation in the History of Ideas. A Brief View and Survey of Bevir and Skinner, "Intellectual History Review", vol. 21, pp. 71-84.

Weber, M. 1904. Die »Objektivität« sozialwissenschaftlicher und sozialpolitischer Erkenntnis, [in:] Id., Gesammelte Aufsätze zur Wissenshaftslehre, J. Winckelmann (ed.), Mohr, Tübingen 1985', pp. 146-214.

Weber, M. 1917. Der Sinn der »Wertfreiheit« der soziologischen und ökonomischen Wissenschaften, [in:] Id., Gesammelte Aufsätze zur Wissenshaftslehre, J. Winckelmann (ed.), Mohr, Tübingen 1985', pp. 489-540.

Weldon, Th. D. 1946. States and Morals: A Study in Political Conflicts, John Murray, London.

\section{BIOGRAPHY}

Boris Manov, full Professor at the Faculty of Philosophy of the South-West University "Neofit Rilski" in Blagoevgrad (Bulgaria), where he teaches political science and history of political ideas. He has published extensively in Bulgarian, Russian and English. Among his recent publications is Evrazijstvo v Bolgarii. Nauchno-istoricheskij analiz [Eurasianism in Bulgaria: A Historical Analysis (in Russian)] (Saarbrücken 2014). E-mail: bmanov@swu.bg 